\title{
Study of vulnerability three-story school buildings with reinforced concrete construction in Banda Aceh to earthquake and tsunami hazards
}

\author{
Natasya Amalia ${ }^{*}$, Yushar ${ }^{2}$, and Winda Yursilla ${ }^{3}$ \\ ${ }^{1}$ Student of Civil Engineering Department, Postgraduate Program, Syiah Kuala University, Jl. Syeh Abdurrauf, No. 7, Banda Aceh, \\ 23111, Indonesia \\ ${ }^{2}$ Bachelor Degree of Economic Development Department, Syiah Kuala University, Jl. Teuku Nyak Arief, Kopelma Darussalam, \\ Banda Aceh, 23111, Indonesia \\ ${ }^{3}$ Graduate of Biology Teacher Education Program, Syiah Kuala University, Jl. Tgk. Hasan Krueng Kalee, Kopelma Darussalam, \\ Banda Aceh, Aceh 24415, Indonesia
}

\begin{abstract}
The city of Banda Aceh is an area located between two active faults, namely, the Aceh segment and the Seulimuem fault. In 2004, an earthquake measuring 9.3 on the Richter Scale rocked the city of Banda Aceh, followed by a tsunami on the Burma Plate. As a result, almost all school buildings were damaged. This study aims to determine the vulnerability of school buildings in Banda Aceh City to earthquake and tsunami hazards from the capacity of the building structure, so that the level of damage is obtained from the developed fragility curve. The object of this research is a typical three-story reinforced concrete school building, namely the private school of Budi Dharma and the national school of SD Negeri 50 in Banda Aceh City. The research was conducted by means of a field survey to collect data on the structure of the school building. The data consists of building data, material quality and building dimensions. Then the loadings are inputted into the SAP2000 program in the form of dead loads, live loads, earthquake loads consisting of the USGS earthquake recording and an estimated map of the Indonesian earthquake, and tsunami loads in 2017. Then pushover analysis was used to get the level of damage from the capacity curve to see the probability percentage comparison. In addition, the large value of $S_{a}$ is equal to the percentage of probability as the level of damage to the building which was influenced by the building of the private school of Budi Dharma that was established before the tsunami on December 26, 2004. We concluded that the greater the value of the height of the tsunami inundation is equal to the level of light, medium, heavy and total damage, at the building of the national school of SD Negeri 50, Banda Aceh as the value of the deviation between the floors of the building from the tsunami load.
\end{abstract}

\section{Introduction}

Indonesian, especially Aceh Province, has a history of earthquakes due to the presence of two active faults, namely Aceh and Seulimuem segments. In 2004, an extreme earthquake measuring 9.3 on the Richter Scale rocked the city of Banda Aceh which occurred under the sea, when the Indian Plate was pushed down by the Burma Plate and was followed by a series of tsunamis. The impact of this disaster was quite significant, almost all structural and infrastructure buildings, public facilities, and other buildings were damaged.

One of the public buildings is a school building which is used for educational infrastructure. It is very important to estimate the vulnerability of school buildings against earthquakes and tsunamis because school buildings carry a high average living load. Therefore, the design of buildings in earthquake-prone areas must adhere to earthquake and tsunami standards.

Generally, a typical school building in the city of Banda Aceh consists of two types of buildings based on load-bearing systems, namely reinforced concrete and masonry. Reinforced concrete is a typical load-bearing building using reinforced concrete structures, while masonry walls use a typical load-bearing building with walls. These two typical load-bearing structures have different susceptibility to earthquake loads. This study takes a typical reinforced concrete load-bearing building.

As a result, damage to buildings due to earthquakes can be seen and the level of vulnerability predicted by referring to the fragility curve. The fragility curve is a curve that shows how big the probability of a building's vulnerability when exposed to an earthquake (NIBS, 2002). Fragile curves are needed to assess the vulnerability of existing school buildings in Banda Aceh City after the 2004 earthquake and tsunami. The fragility curve will show the level of damage to the building structure with various discrete damage conditions, such as slight damage, moderate damage, extensive damage, and complete damage. modeled using pushover analysis in SAP2000 v.20 software.

\footnotetext{
* Natasya Amalia: tasya110@gmail.com
} 
Furthermore, the results of this study determine the vulnerability of a building obtained from the fragility curve developed and the capacity curve to see the level of damage and the probability percentage due to earthquake and tsunami loads. The results of the analysis that are reviewed are the value of building displacement and the deviation between floors from the tsunami load. So that it can be recommended improvements and various efforts to improve the structure of the building can be done to reduce these risks.

\section{Literature review}

\subsection{Earthquake}

Earthquake is a movement or vibration that occurs in the earth's crust caused by endogenous forces. Endogenous energy itself is energy from within the earth caused by changes in the earth's crust [1].

\subsection{Tsunami}

The tsunami, according to the Center for Volcanology and Geological Hazard Mitigation or PVMBG (2006) explains that a tsunami is a natural disaster in the form of ocean waves caused by an earthquake on the seabed and has the ability to spread at high speed, even the speed can exceed $900 \mathrm{~km} /$ hour. Puspito (2010) added that tsunamis can reach a height of one meter or even tens of meters from the coastline.

\subsection{Structure loading}

\subsubsection{Dead load}

Based on SNI 1727:2020 [2], dead load is the weight of all installed building construction materials, including architectural components, structural components and non-structural components as well as other installed service equipment.

\subsubsection{Live load}

Live loads are loads caused by users and occupants of buildings or other structures that are not included in construction loads (SNI 1727:2020) [2]. The minimum evenly distributed live load is in SNI 1727:2020 [2].

\subsubsection{Earthquake loads}

Earthquake loads are all equivalent static loads acting on buildings or parts of buildings that mimic the effects of ground motion due to the earthquake. Building planning against earthquake loads can be seen in SNI 1726:2019 [3].

\subsubsection{Tsunami load}

Tsunami waves cannot be seen when they are far in the middle of the ocean, but once they reach shallow areas the waves will move quickly. The energy generated by the tsunami is fixed to the function of altitude and its continuation (Sugito, 2008). The energy forms the forces that will become a load on the building structure.

\subsubsection{Loading combination}

According to SNI 1726-2019 [3], the factors and load combinations for nominal dead load (D), nominal live load (L) and nominal earthquake load $\left(\mathrm{Q}_{\mathrm{E}}\right)$ that must be reviewed are as follows:

$$
\begin{aligned}
& \mathrm{U}_{1}=1,4 \mathrm{D} \\
& \mathrm{U}_{2}=1,2 \mathrm{D}+1,6 \mathrm{~L} \\
& \mathrm{U}_{3}=1,38 \mathrm{D}+1 \mathrm{~L}+0,39 \mathrm{QEx}_{\mathrm{Ex}}+1,3 \mathrm{QEy}_{\mathrm{E}} \\
& \mathrm{U}_{4}=1,38 \mathrm{D}+1 \mathrm{~L}+0,39 \mathrm{QEx}_{\mathrm{Ex}}-1,3 \mathrm{QEy} \\
& \mathrm{U}_{5}=1,38 \mathrm{D}+1 \mathrm{~L}-0,39 \mathrm{QEx}_{\mathrm{Ex}}-1,3 \mathrm{QEy} \\
& \mathrm{U}_{6}=1,38 \mathrm{D}+1 \mathrm{~L}-0,39 \mathrm{QEx}_{\mathrm{Ex}}+1,3 \mathrm{QEy}_{\mathrm{E}} \\
& \mathrm{U}_{7}=1,38 \mathrm{D}+1 \mathrm{~L}+1,3 \mathrm{QEx}_{\mathrm{Ex}}+0,39 \mathrm{QEy} \\
& \mathrm{U}_{8}=1,38 \mathrm{D}+1 \mathrm{~L}+1,3 \mathrm{QEx}_{\mathrm{Ex}}-0,39 \mathrm{QEy} \\
& \mathrm{U}_{9}=1,38 \mathrm{D}+1 \mathrm{~L}-1,3 \mathrm{QEx}_{\mathrm{Ex}}-0,39 \mathrm{QEy} \\
& \mathrm{U}_{10}=1,38 \mathrm{D}+1 \mathrm{~L}-1,3 \mathrm{QEx}_{\mathrm{Ex}}+0,39 \mathrm{QEy} \\
& \mathrm{U}_{11}=1,08 \mathrm{D}+0,39 \mathrm{QEx}_{\mathrm{Ex}}+1,3 \mathrm{QEy} \\
& \mathrm{U}_{12}=1,08 \mathrm{D}+0,39 \mathrm{Q}_{\mathrm{Ex}}-1,3 \mathrm{Q} \text { Ey } \\
& \mathrm{U}_{13}=1,08 \mathrm{D}-0,39 \mathrm{Q}_{\mathrm{Ex}}-1,3 \mathrm{Q} \text { Ey } \\
& \mathrm{U}_{14}=1,08 \mathrm{D}-0,39 \mathrm{QEx}_{\mathrm{Ex}}+1,3 \mathrm{QEy} \\
& \mathrm{U}_{15}=1,08 \mathrm{D}+1,3 \mathrm{QEx}-0,39 \mathrm{QEy} \\
& \mathrm{U}_{16}=1,08 \mathrm{D}+1,3 \mathrm{QEx}_{\mathrm{Ex}}+0,39 \mathrm{QEy} \\
& \mathrm{U}_{17}=1,08 \mathrm{D}-1,3 \mathrm{QEx}_{\mathrm{Ex}}-0,39 \mathrm{Q} \text { Ey } \\
& \mathrm{U}_{18}=1,08 \mathrm{D}-1,3 \mathrm{QEx}_{\mathrm{Ex}}+0,39 \mathrm{QEy}
\end{aligned}
$$

$\rho$ is the redundancy factor, which must be applied to the seismic force resisting system in each of the two orthogonal directions for all structures. The provisions for the value of can be seen in SNI 1726-2019 [3].

The load combinations for the tsunami based on FEMA P646 are as follows [4]:

$$
\begin{aligned}
& \mathrm{U} 19=1,2 \mathrm{D}+1,0 \mathrm{~T}_{\mathrm{S}}+1,0 \mathrm{~L}_{\mathrm{REF}}+0,25 \mathrm{~L} \\
& \mathrm{U} 20=0,9 \mathrm{D}+1,0 \mathrm{~T}_{\mathrm{S}}
\end{aligned}
$$

\subsection{Design response spectrum}

According to SNI 1726:2019 [3], the response spectrum is a spectrum presented in the form of a graph/plot that explains the relationship between the maximum response acceleration of a system of one degree of freedom due to a particular earthquake, as a function of the damping factor and natural vibration time. For periods greater than or equal to $T_{0}$ and less than or equal to $T_{\mathrm{s}}$, the design acceleration response spectrum $\left(\mathrm{S}_{\mathrm{a}}\right)$ is the same as $S_{D S}$.

\subsection{Capacity curve}

According to Dewobroto [5], pushover analysis is carried out by applying a lateral load in a certain pattern 
with a simulated earthquake load and must be given together with the combined effect of dead loads and not less than $25 \%$ of the required live load. Lateral loads must be applied to the center of mass for each story. From the pushover analysis will produce a capacity curve, which describes the relationship between the base shear and the displacement of the reference point on the roof structure. The capacity curve will show a linear condition before reaching the melting state and then behave non-linearly. This curve is influenced by the distribution pattern of the lateral force used as the thrust load. The main purpose of this earthquake susceptibility curve is to estimate the value of peak ground motion acceleration where the earthquake response of a structure exceeds the capacity resulting in structural failure.

\subsection{Fragility curve}

\subsubsection{Seismic fragility curve}

Duan \& Pappin [6] in their research proposed a procedure to determine the median spectra displacement point at various damage conditions based on the results of nonlinear static pushover analysis. The steps of the procedure are described as follows.

a. Perform nonlinear static pushover analysis to get curve (spectrum)

b. Identifying the spectral displacement value on the yielding capacity (spectrum) curve. This is the median point of the yielding capacity.

c. Identify the spectral dispacement value when the first component reaches a complete breakdown condition. According to HAZUS [7] recommendation, this point is the median spectral displacement for slight damage conditions.

d. The median spectral displacement value for moderate damage conditions can be obtained by shifting the spectral displacement medium from slight damage conditions by a factor of 1.5 .

e. Identify the spectral displacement with the collapse point on the capacity curve as the median spectral displacement point for complete damage conditions.

f. The median spectral displacement value for extensive damage conditions can be determined by placing it in the middle between the median points for moderate and complete damage conditions on a $\log$ scale.

Several damage limit criteria can be used in determining the performance of the structure based on the capacity curve. The limits for damage to building structures can be seen in Table 1.

Table 1. Description of structure performance limitations based on Hazus

\begin{tabular}{|c|l|}
\hline $\begin{array}{c}\text { Damage } \\
\text { State }\end{array}$ & \multicolumn{1}{c|}{ Description of the damage that occurred } \\
\hline & $\begin{array}{l}\text { The plaster of the walls had small cracks in the } \\
\text { corners of the door and window openings. Small } \\
\text { cracks are considered visible with a maximum } \\
\text { width of less than } 1 / 8 \text { inch (cracks wider than } 1 / 8 \\
\text { inch are referred to as "large" cracks). }\end{array}$ \\
\hline
\end{tabular}

\begin{tabular}{|c|c|}
\hline 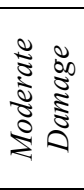 & $\begin{array}{l}\text { The plaster of the walls has major cracks, large } \\
\text { cracks in the door and window openings, on some } \\
\text { of the columns there are shards and cracks that are } \\
\text { rather large but the columns can still safely stand } \\
\text { upright. }\end{array}$ \\
\hline 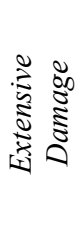 & $\begin{array}{l}\text { Large cracks in the shear wall panels, large cracks } \\
\text { in the joints between the columns and beams, } \\
\text { several columns were damaged badly enough to no } \\
\text { longer be safe as the main support for the structure, } \\
\text { the floor slabs experienced large cracks, and the } \\
\text { foundation structure suffered large cracks. }\end{array}$ \\
\hline 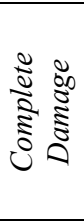 & $\begin{array}{l}\text { The structure of the building may be in danger of } \\
\text { collapsing due to failure of fragile walls, cracks in } \\
\text { large foundations, some of the columns have } \\
\text { collapsed. Three percent of the total building area } \\
\text { with total damage is expected to collapse, on } \\
\text { average. }\end{array}$ \\
\hline
\end{tabular}

The seismic fragility curve of the building will describe the probability of damage to the building based on the acceleration spectra as shown in Fig. 1.
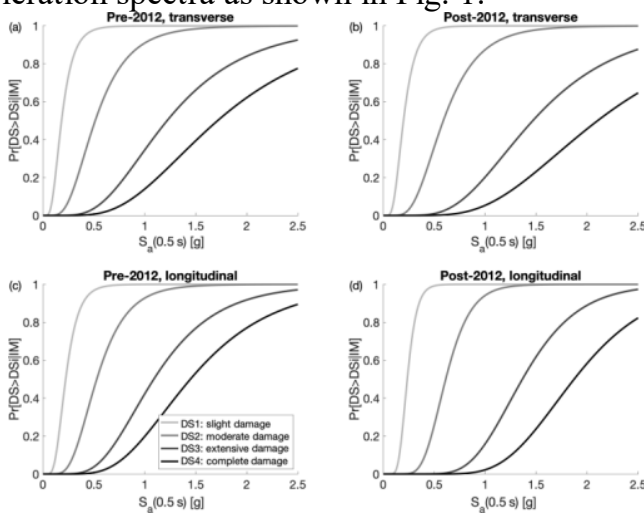

Fig. 1. Seismic fragility curves for typical buildings

\subsubsection{Tsunami fragility curve}

The assessment of building damage due to the tsunami can be described by means of a fragility curve. The tsunami fragility curve function was developed to estimate the impact of future tsunamis. The level of damage is classified into five kerus status from the curve, as shown in Figure 2.

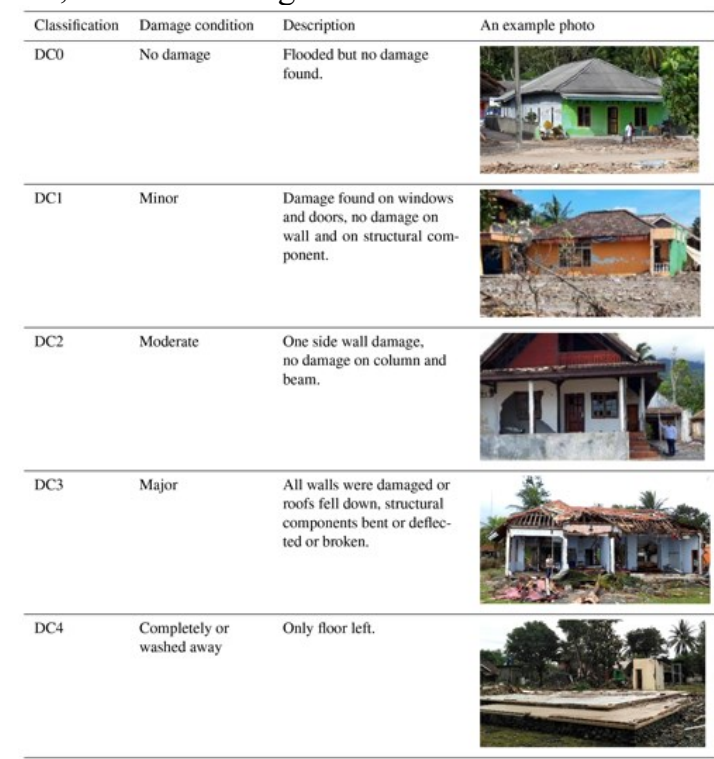

Fig. 2. The performance limitations of structure 
The tsunami fragility curve as shown in Figure 3.

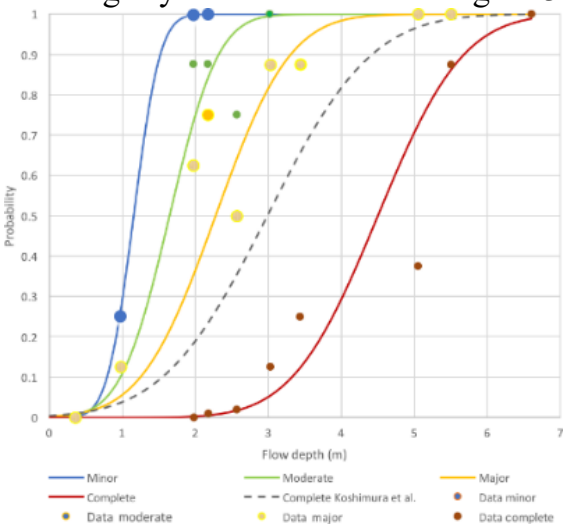

Fig. 3. Tsunami fragility curves for typical buildings

\section{Research methods}

\subsection{Object of research}

The object of research in this study is a typical threestory reinforced concrete school building located in the city of Banda Aceh using a rapid assessment survey. The study took 2 typical buildings from the survey results of 100 three-story school buildings and took the typical structure that dominates the structural design of the building, then looked at the location for building selection.

\subsection{Data types and sources}

The types of data needed in this research are primary data obtained directly through field surveys on school buildings in the city of Banda Aceh as well as, secondary data for supporting data together with a reference for the implementation of the primary survey. Meanwhile, the literature used in this study comes from journals, websites, books related to earthquake analysis which are included in the pushover analysis. The regulations used include SNI-1726-2019 [3] concerning Procedures for Planning Earthquake Resistance for Building and NonBuilding Structures, SNI-03-1727-2013 [8] concerning Minimum Loads for Designing Buildings and Other Structures, Map Sources and Hazards of the 2017 Indonesian Earthquake, as well as books related to this research.

\subsection{Data collection technique}

Research data collection was carried out by means of a field survey. The survey was used to collect building structure data in the form of structural dimensions of the building and building vulnerability factors from the two school buildings surveyed. The survey was ealuated firsthand how the condition of the building. To complete the data on the survey form, a map of the fault location is needed together with tsunami data analysis by SAP2000 v.20, while the data is inputted directly from the developed earthquake and tsunami fragility curve, converted using an online graphreader application as shown in Figure 4.

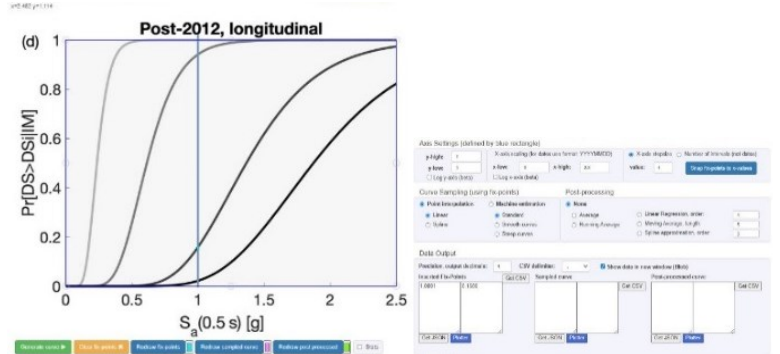

Fig. 4. Display of image input and online graphreader application data results

\subsubsection{Building technical data}

Based on field research, there is excess reinforcement visible in the beam so that it can be used as a source for modeling school building structures. As taken from Gentile's research [9], from the results of his research on From Rapid Visual Survey to Multi-Hazard Risk Prioritization and Numerical Fragility of School Buildings in Banda Aceh, Indonesia, typical details of building structures for various forms of buildings in Banda Aceh as shown in Table 2.

Table 2. Typical quality of concrete and steel reinforcement for school buildings in Banda Aceh.

\begin{tabular}{|c|c|c|c|c|}
\hline$\underset{\nearrow}{\beth}$ & Material & $\begin{array}{l}\text { Typical } \\
\text { Beam }\end{array}$ & $\begin{array}{l}\text { Typical } \\
\text { Column }\end{array}$ & $\begin{array}{c}\text { Typical } \\
\text { Join }\end{array}$ \\
\hline \multirow{3}{*}{ 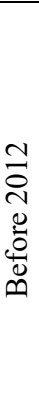 } & $\begin{array}{l}\text { Concrete fc } \\
=21.5 \mathrm{MPa}\end{array}$ & $3 \Phi 16$ up & $3 \Phi 16$ up & $\begin{array}{l}\text { without } \\
\text { Sengkang }\end{array}$ \\
\hline & $\begin{array}{l}\text { Bones Lon. } \\
\mathrm{fy}=400 \\
\mathrm{MPa}\end{array}$ & $\begin{array}{l}3 \Phi 16 \\
\text { down }\end{array}$ & $\begin{array}{l}3 \Phi 16 \\
\text { down }\end{array}$ & \\
\hline & $\begin{array}{l}\text { Tran Bone. } \\
\text { fy }=240 \\
\mathrm{MPa}\end{array}$ & $\begin{array}{l}\text { Sengkang } \\
\Phi 10-150 \\
\mathrm{~mm}\end{array}$ & $\begin{array}{l}\text { Sengkang } \\
\Phi 10-200 \\
\mathrm{~mm}\end{array}$ & \\
\hline \multirow{3}{*}{ 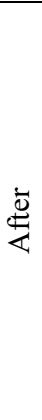 } & $\begin{array}{l}\text { Concrete fc } \\
=24 \mathrm{Mpa}\end{array}$ & $3 \Phi 16$ up & $3 \Phi 16$ up & $\begin{array}{l}\text { without } \\
\text { Sengkang }\end{array}$ \\
\hline & $\begin{array}{l}\text { Bones Lon. } \\
\mathrm{fy}=400 \\
\mathrm{MPa}\end{array}$ & $\begin{array}{l}3 \Phi 16 \\
\text { down }\end{array}$ & $\begin{array}{l}3 \Phi 16 \\
\text { down }\end{array}$ & \\
\hline & $\begin{array}{l}\text { Tran Bone. } \\
\text { fy }=240 \\
\mathrm{MPa}\end{array}$ & $\begin{array}{l}\text { Sengkang } \\
\Phi 10-150 \\
\mathrm{~mm}\end{array}$ & $\begin{array}{l}\text { Sengkang } \\
\Phi 10-100 \\
\mathrm{~mm}\end{array}$ & \\
\hline
\end{tabular}

\subsubsection{Earthquake data}

Earthquake data used in this study is a scenario recording of the earthquake in the Sumatra - Andaman fault on December 26, 2004 obtained from the United States Geological Survey or USGS and earthquake forecast data obtained from the portal of the Center for Research and Development of Housing and Settlements (PUSKIM) based on maps. Indonesia earthquake 2017. Furthermore, in the discussion results chapter it is called "USGS earthquake recording" and the estimated load for 
the 2017 Indonesian earthquake map is referred to in the discussion results chapter as "estimated Indonesia earthquake map 2017".

\subsubsection{Tsunami data}

Banda Aceh is located between the $200 \mathrm{~km}$ long Aceh segment and the $120 \mathrm{~km}$ Seulimum segment. The existence of this segment results in vulnerability to earthquakes and tsunamis. The estimated height of the tsunami inundation in Banda Aceh City was obtained from the research of Iemura, et al [10].

1. Combined earthquake loading

The seismic design category for the second typical building is category $\mathrm{D}$ and the redundancy factor used $(\rho)$ is 1.3. This study did not review the soil conditions, so that the lateral soil load $(\mathrm{H})$ was considered 0 . To obtain the ultimate load from the loads that might occur on the structure, a combination of factored loads was carried out. Combination of loading as the equation 118.

The results of the run analysis of each combination will shown as a combination that results in the largest structural deformation. The result will be used for a displacement control in the pushover analysis.

\section{Combination of tsunami loading}

The combination of tsunami loading is similar to the equation 19-20.

\subsection{Pushover analysis}

Analysis of pushover loading in stages, the direction of lateral loading was carried out in the direction of the main axis of the building. Lateral loading uses the displacement-controlled concept, namely, the loading process is increased gradually until the displacement target is achieved.

\subsubsection{Gravity loading}

In the static thrust load analysis, the percentage of the load used in the gravity load is $100 \%$ dead load (including additional dead load) and 50\% live load. Gravity loading is carried out on the Load Case Name named "Grav" where the loading is carried out at the initial condition before receiving the load. In Load Applied, 2 types of working loads are used, namely dead loads and live loads with each scale factor given 1 . Then the Analysis type was selected Nonlinear analysis because what will be done is nonlinear analysis.

\subsubsection{Lateral loading}

In this analysis, two directions of lateral loading were made as pushover loads, namely the $\mathrm{X}$ direction and the $\mathrm{Y}$ direction. Lateral loads were added to the Load Case Data table.

\subsection{Data analysis}

\subsubsection{Analysis of the seismic performance limits of the developed capacity spectrum curve}

The capacity spectrum curve that gets the value of the median spectral acceleration $\left(\mathrm{S}_{\mathrm{a}}\right)$ parameter is one of the important parameters to get the probability of structural failure $(\mathrm{P})$ which is used to analyze the seismic fragility curve. To get the median spectral acceleration $\left(\mathrm{S}_{\mathrm{a}}\right)$ value, it is necessary to convert the capacity curve which is the basic shear force curve $(\mathrm{V})$ to roof/floor displacement ( $\Delta$ roof) into a capacity spectrum curve which is the spectral acceleration curve $\left(\mathrm{S}_{\mathrm{a}}\right)$ to spectral displacement $\left(\mathrm{S}_{\mathrm{d}}\right)$ and can be seen in section 2.4 page 15. In section 2.8.1 page 19 it has been explained that the table was identified according to the analysis proposed by Duan and Pappin (2008) to obtain the values of the median spectral displacement and median spectral acceleration at various levels of damage.

The final result of this study is to analyze the level of damage obtained from the fragility curve developed by using the fragility curve from the journal Natural Hazards and Earth System Sciences by Gentile, et al. [9], a building that shows the probability of damage to the building when it receives an earthquake load with a certain intensity. Then, it is also shown when each of these buildings was built, so that the curve after or after the tsunami 2004 can be used. The fragility curve will show the percentage of the probability of damage to the building structure with various damage conditions, namely light damage, moderate damage, severe damage, and total damage. The median spectral acceleration at various levels of damage is obtained from the capacity spectrum curve. As well as reviewing the value of the acceleration spectra on the response curve of the capacity spectrum in order to see the condition of the location of the level of damage to the building.

\subsubsection{Tsunami analysis}

This study also was analyzed the calculation of the tsunami load for the risk of reducing damage to building structures in the event of a tsunami disaster. The displacement is obtained by entering the load on the column structure with a height as high as the depth of the tsunami flow, for each building, namely the private junior high school of Budi Dharma (Sekolah Budi Dharma) with a flow depth of 1.8 meters, the elevation of the base of the building to the water level elevation as high as 2 meters and for the national elementary school 50 (SD Negeri 50) with a flow depth of 2.6 meters, the elevation of the base of the building to the water level as high as 2 meters, the height is taken according to the sub-district because the school area was not hit by the tsunami, only entered the height to show the condition of the school building if it was hit by a tsunami disaster. After that, an analysis was carried out on SAP2000 v.20 to compare the height of the tsunami with the probability of the fragility curve that was developed (the vulnerability curve of the Volcanogenic tsunami of Mount Anak Krakatau, research by Syamsidik, et al [11] on the two typical school buildings. 


\section{Results and discussions}

\subsection{Survey data recapitulation results}

The determination of school buildings was carried out from the results of data recapitulation based on the selection of buildings that are typical school buildings in the city of Banda Aceh. The results of data recapitulation in the form of infographics is shown in Figure 6 dan Figure 7.

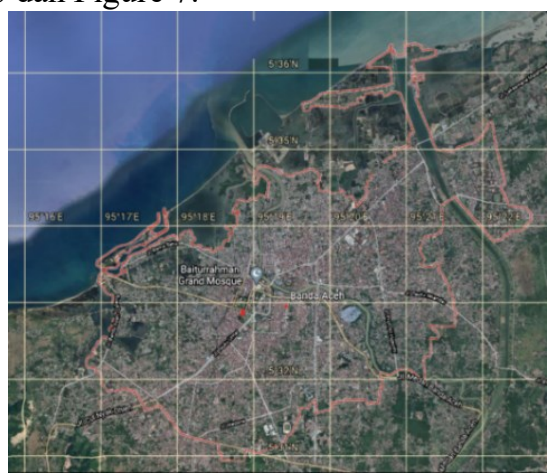

Fig. 6. Map of Banda Aceh (research location Budi Dharma School)

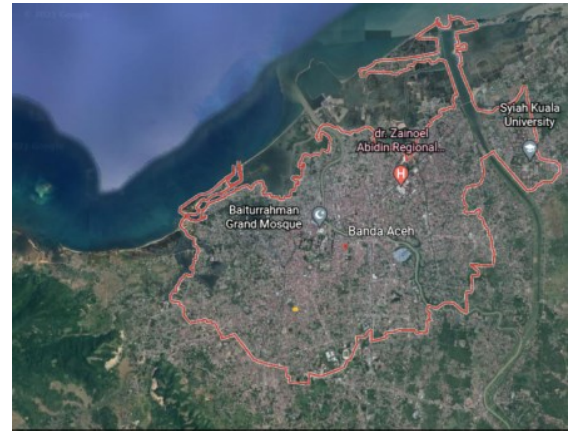

Fig. 7. Map of Banda Aceh (research location SD Negeri 50)

Based on the results of the data recapitulation of 100 school buildings, the selection of school buildings by looking at the relatively close distance to the shore and faults, while the selection of these buildings can be concluded that the criteria for the two forms of school buildings that dominate in the city of Banda Aceh as follow:

- Building shape

: Type I (top view of Ishaped building)

- Number of floors

- Height per floor

$: 3$

- $\quad$ Long

$: 3.5 \mathrm{~m}$

- Wide

: $24 \mathrm{~m}$ and $40 \mathrm{~m}$

- Composition material : Reinforced Concrete (RC) School buildings that meet the criteria from the conclusions above are Sekolah Budi Dharma and SD Negeri 50.

The data obtained in the field for the Sekolah Budi Dharma and SD Negeri 50 Banda Aceh in the form of building characteristics, position, structural dimensions, and reinforcement details is shown in Tables $3-8$.
Table 3. Characteristics and position of the Sekolah Budi Dharma and SD Negeri 50 Banda Aceh

\begin{tabular}{|c|c|c|c|}
\hline No & Criteria & $\begin{array}{c}\text { Sekolah Budi } \\
\text { Dharma }\end{array}$ & SD Negeri 50 \\
\hline 1 & $\begin{array}{l}\text { Place } \\
\text { Coordinates }\end{array}$ & $\begin{array}{l}\text { Longitudinal } \\
95.3145, \\
\text { Lateral } 5.5478\end{array}$ & $\begin{array}{l}\text { Longitunal } \\
95.31128, \\
\text { Lateral } 5.53396\end{array}$ \\
\hline 2 & $\begin{array}{l}\text { Construction } \\
\text { year }\end{array}$ & $2001-2005$ & $2016-2017$ \\
\hline 3 & $\begin{array}{l}\text { Distance to } \\
\text { fault }\end{array}$ & $3 \mathrm{Km}$ & $6 \mathrm{Km}$ \\
\hline 4 & Total students & - person & - person \\
\hline 5 & $\begin{array}{l}\text { Number of } \\
\text { floors }\end{array}$ & 3 floors & 3 floors \\
\hline 6 & Height/floor & 3 meters & 3 meters \\
\hline 7 & Material & $\begin{array}{l}\text { Reinforced } \\
\text { Concrete } \\
(R C)\end{array}$ & $\begin{array}{l}\text { Reinforced } \\
\text { Concrete }(R C)\end{array}$ \\
\hline 8 & $\begin{array}{l}\text { Space frame } \\
\text { system }\end{array}$ & Frames & Frames \\
\hline 9 & Roof shape & Multi Pitch & Multi Pitch \\
\hline 10 & Roof type & Wood frame & Wood frame \\
\hline
\end{tabular}

Tabel 4. Plate reinforcement dimensions and details

\begin{tabular}{|c|c|c|c|}
\hline Type & $\begin{array}{c}\text { Plate } \\
\text { Thickness }(\mathrm{mm})\end{array}$ & Position & reinforcement \\
\hline \multirow{2}{*}{ Floor } & \multirow{2}{*}{120} & focus & D 10-200 \\
\hline & & Field & D $10-200$ \\
\hline \multirow{2}{*}{ Ladder } & \multirow{2}{*}{120} & focus & D 13-150 \\
\hline & & Field & D 13-150 \\
\hline
\end{tabular}

Tabel 5. Dimensions and details of the beam reinforcement of the Sekolah Budi Dharma of Banda Aceh

\begin{tabular}{|c|c|c|c|c|c|}
\hline \multirow{2}{*}{ i் } & \multirow{2}{*}{ 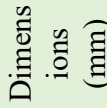 } & \multirow{2}{*}{ Position } & \multicolumn{3}{|c|}{ reinforcement } \\
\hline & & & Top & Bottom & Stirrup \\
\hline \multirow{2}{*}{ 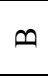 } & \multirow{2}{*}{$\begin{array}{c}300 \mathrm{x} \\
800\end{array}$} & Tumpuan & $4 \Phi 16$ & $4 \Phi 16$ & $\Phi 10-100 \mathrm{~mm}$ \\
\hline & & Lapangan & $4 \Phi 16$ & $4 \Phi 16$ & $\Phi 10-100 \mathrm{~mm}$ \\
\hline \multirow[b]{2}{*}{ ๓ี } & \multirow{2}{*}{$\begin{array}{c}300 \mathrm{x} \\
500\end{array}$} & Tumpuan & $4 \Phi 16$ & $4 \Phi 16$ & $\Phi 10-100 \mathrm{~mm}$ \\
\hline & & Lapangan & $4 \Phi 16$ & $4 \Phi 16$ & $\Phi 10-100 \mathrm{~mm}$ \\
\hline
\end{tabular}

Tabel 6. Dimensions and details of beam reinforcement for

\begin{tabular}{|c|c|c|c|c|c|}
\hline \multicolumn{6}{|c|}{ SD Negeri 50 Banda Aceh } \\
\hline \multirow{2}{*}{$\begin{array}{l}0 \\
0 \\
0 \\
0\end{array}$} & \multirow{2}{*}{ 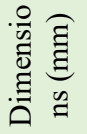 } & \multirow{2}{*}{ Position } & \multicolumn{3}{|c|}{ reinforcement } \\
\hline & & & Top & Bottom & Stirrup \\
\hline \multirow{2}{*}{ B1 } & \multirow{2}{*}{$\begin{array}{c}300 x \\
600\end{array}$} & Tumpuan & $4 \Phi 16$ & $4 \Phi 16$ & $\Phi 10-100 \mathrm{~mm}$ \\
\hline & & Lapangan & $4 \Phi 16$ & $4 \Phi 16$ & $\Phi 10-100 \mathrm{~mm}$ \\
\hline
\end{tabular}

Tabel 7. Dimensions and details of the reinforcement of the Sekolah Budi Dharma Banda Aceh column

\begin{tabular}{|c|c|c|c|c|c|}
\hline \multirow[b]{2}{*}{$\begin{array}{l}8 \\
0 \\
0\end{array}$} & \multirow{2}{*}{ 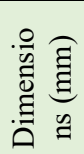 } & \multirow[b]{2}{*}{ Position } & \multicolumn{3}{|c|}{ reinforcement } \\
\hline & & & Top & Bottom & Stirrup \\
\hline \multirow{2}{*}{ K1 } & \multirow{2}{*}{$\begin{array}{c}300 x \\
600\end{array}$} & Tumpuan & $4 \Phi 16$ & $4 \Phi 16$ & $\Phi 10-150 \mathrm{~mm}$ \\
\hline & & Lapangan & $4 \Phi 16$ & $4 \Phi 16$ & $\Phi 10-150 \mathrm{~mm}$ \\
\hline \multirow{2}{*}{ K2 } & \multirow{2}{*}{$\begin{array}{c}350 x \\
400\end{array}$} & Tumpuan & $4 \Phi 16$ & $4 \Phi 16$ & $\Phi 10-150 \mathrm{~mm}$ \\
\hline & & Lapangan & $4 \Phi 16$ & $4 \Phi 16$ & $\Phi 10-150 \mathrm{~mm}$ \\
\hline
\end{tabular}


Tabel 8. Dimensions and details of the reinforcement of the SD Negeri 50 Banda Aceh column

\begin{tabular}{|c|c|c|c|c|c|}
\hline \multirow[b]{2}{*}{ ن } & \multirow{2}{*}{ 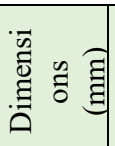 } & \multirow[b]{2}{*}{ Position } & \multicolumn{3}{|c|}{ reinforcement } \\
\hline & & & On & Bawah & Sengkang \\
\hline \multirow{2}{*}{ K1 } & \multirow{2}{*}{$\begin{array}{c}400 x \\
500\end{array}$} & Tumpuan & $4 \Phi 16$ & $4 \Phi 16$ & $\Phi 10-150 \mathrm{~mm}$ \\
\hline & & Lapangan & $4 \Phi 16$ & $4 \Phi 16$ & $\Phi 10-150 \mathrm{~mm}$ \\
\hline
\end{tabular}

\subsection{Number of variety analysis results}

Modal analysis was used to evaluate the effective mass participation of variance whose magnitude must be greater than $90 \%$, this value is obtained directly from SAP2000, the mass variance value for the USGS earthquake record and the estimated Indonesia earthquake map 2017 produces the same value, these values is shown in Table 9 below.

Tabel 9. Effective Mass Diversity Participation the USGS earthquake record and the estimated Indonesia earthquake

\begin{tabular}{|c|c|c|c|c|}
\hline Bang & Tipe Modal & Item & $\begin{array}{c}\text { Static } \\
(\%)\end{array}$ & $\begin{array}{c}\text { Dynamic } \\
(\%)\end{array}$ \\
\hline \multirow{3}{*}{$\begin{array}{c}\text { SMP } \\
\text { BUDI } \\
\text { DARMA }\end{array}$} & & UX & 100 & 99,5995 \\
\hline & Acce & UY & 100 & 99,2 \\
\hline & Accel & $\overline{\mathrm{UZ}}$ & 0,2475 & 0,0467 \\
\hline \multirow{3}{*}{$\begin{array}{c}\text { SDN } 50 \\
\text { Banda } \\
\text { Aceh }\end{array}$} & Acceieration & UX & 4 & 92,3549 \\
\hline & Acceleration & $\overline{U Y}$ & 99,1355 & 92,7287 \\
\hline & Acceleration & $\mathrm{UZ}$ & 0,1183 & 0,0022 \\
\hline
\end{tabular}

Based on the table above for the USGS earthquake records and the estimated Indonesia earthquake map 2017 was reviewed in the two buildings, it shows that the mass participation value of variance has met the provisions of the SNI 03-1726 - 2019 limit, namely the effective variance mass participation factor for the $\mathrm{x}$ direction and y-direction of a minimum of $90 \%$.

\subsection{Structural fundamental period analysis}

In the fundamental period of the structure (the period of structural vibration) the symbol $\mathrm{T}$ is a very important property in the design process of earthquake-resistant building structures. The period of vibration of the structure will determine the magnitude of the earthquake load applied in the design of the structure.

From the results of SAP2000, the natural fundamental period time $\mathrm{T}=0,518$ for Sekolah Budi Dharma and $\mathrm{T}=0,611$ for SD Negeri 50 with Ta max obtained from the calculation of SNI 1726-2019. So, T analysis $<$ Ta max, then the structure is declared to have met the conditions for the permit fundamental period obtained from the calculation of SNI 1726-2019.
Tabel 10. The results of the analysis of the fundamental vibration time of the building structure

\begin{tabular}{|c|c|c|c|c|}
\hline \multirow{2}{*}{ Building } & 总 & Periode & $\mathbf{T}_{\text {aSyarat }}$ & \multirow{2}{*}{ 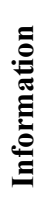 } \\
\hline & 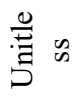 & $\mathrm{Sec}$ & $\mathrm{Sec}$ & \\
\hline \multirow{12}{*}{$\begin{array}{c}\text { SMP BUDI } \\
\text { DARMA }\end{array}$} & 1 & 0,31614 & \multirow{12}{*}{0,518} & \multirow{12}{*}{$\underset{\Xi}{\Xi}$} \\
\hline & 2 & 0,23386 & & \\
\hline & 3 & 0,19872 & & \\
\hline & 4 & 0,18618 & & \\
\hline & 5 & 0,13514 & & \\
\hline & 6 & 0,12224 & & \\
\hline & 7 & 0,11696 & & \\
\hline & 8 & 0,10126 & & \\
\hline & 9 & 0,09100 & & \\
\hline & 10 & 0,06678 & & \\
\hline & 11 & 0,05571 & & \\
\hline & 12 & 0,03758 & & \\
\hline \multirow{12}{*}{$\begin{array}{c}\text { SDN } 50 \\
\text { Banda Aceh }\end{array}$} & 1 & 0,3279 & \multirow{12}{*}{0,611} & \multirow{12}{*}{ 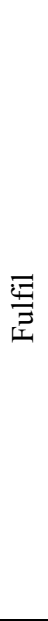 } \\
\hline & 2 & 0,2892 & & \\
\hline & 3 & 0,2718 & & \\
\hline & 4 & 0,2138 & & \\
\hline & 5 & 0,1923 & & \\
\hline & 6 & 0,1889 & & \\
\hline & 7 & 0,1768 & & \\
\hline & 8 & 0,1744 & & \\
\hline & 9 & 0,1643 & & \\
\hline & 10 & 0,1604 & & \\
\hline & 11 & 0,1493 & & \\
\hline & 12 & 0,1372 & & \\
\hline
\end{tabular}

Based on Table 10, the natural period of the building resulting from SAP2000 v.20 has also met SNI $03-$ $1726-2019$ with the limit period for the vibration of the sekolah Budi Dharma building for the USGS earthquake recording and the estimated 2017 Indonesian earthquake map of 0.518 seconds, while the vibration period limit for the building is SDN 50 Records. USGS earthquake and the estimated Indonesia earthquake map 2017 is 0.611 seconds. The limit value of the vibration period in the two buildings is different due to the different building heights.

\subsection{Results of Comparative Evaluation of the Capacity Curves for the USGS earthquake and the estimated Indonesia earthquake map 2017}

The pushover analysis method was aimed at building capacity curves. The capacity curve shows the relationship between the recorded displacement and the resultant shear force caused by the specified displacement target or static load to the ultimate 
building condition. The largest recorded displacement in the $\mathrm{x}$ direction in the Sekolah Budi Dharma building for the USGS earthquake record is found in combination 14 at joint 96 of $0.060599 \mathrm{~m}$ and the y direction is found in combination 6 at joint 119 of $0.272601 \mathrm{~m}$, for the estimated Indonesia earthquake map 2017 is found in combination 4 at joint 108 of $0.22029 \mathrm{~m}$ and the $y$ direction is found in combination 6 at joint 119 of $0.306956 \mathrm{~m}$. While the SD Negeri 50 building for USGS earthquake records is found in combination 12 at joint 151 of $0.075015 \mathrm{~m}$ and the $\mathrm{y}$ direction is found in combination 6 at joint 137 is $0.064917 \mathrm{~m}$, for the estimated Indonesia earthquake map 2017 is found in combination 12 at joint 151 of $0.039657 \mathrm{~m}$ and the $\mathrm{y}$ direction is found in combination 6 at joint 160 of $0.162109 \mathrm{~m}$. Monitored displacement is the point that experiences the largest structural deformation of a combination of factored loads that follow equations (1) to (18). The result of the combined factored load alone.

\subsubsection{Capacity curve for sekolah Budi Dharma of Banda Aceh}

The capacity curve was showed nonlinear due to an increase in load which makes the structural elements of the building change from an elastic condition to a plastic condition, for more details the capacity curve in the $x$ direction and $y$ direction is shown in the figure below.

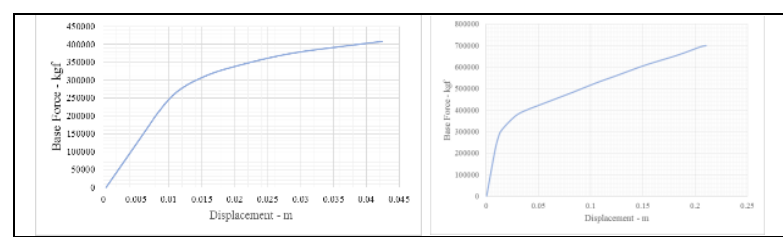

Fig. 8. Capacity curve $x$-direction (USGS Earthquake Record- Estimated Indonesia Earthquake Map 2017)

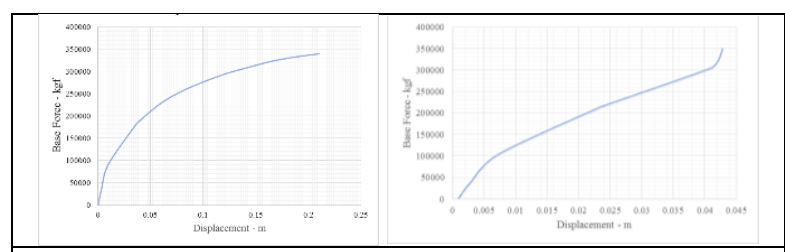

Fig. 9. Capacity curve y-direction (USGS earthquake record- Estimated Indonesia earthquake map 2017)

\subsubsection{Capacity Curve for SD Negeri 50 Banda Aceh}

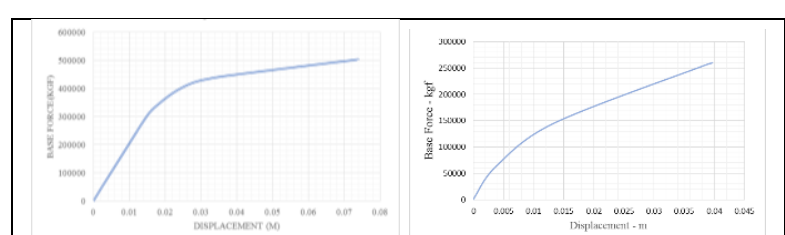

Fig. 10. Capacity curve $x$-direction (USGS Earthquake Record- Estimated Indonesia Earthquake Map 2017)

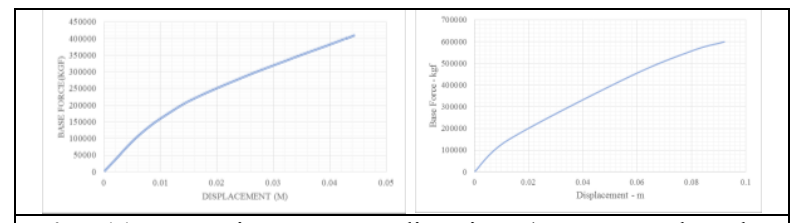

Fig. 11. Capacity curve y-direction (USGS earthquake record- Estimated Indonesia earthquake map 2017)

Based on the capacity curve as shown in Figures 8 - 11, the result indicated the pushover analysis in the $\mathrm{x}$ and $\mathrm{y}$ directions shows the maximum displacement value and the base shear value as shown in Table 11 below.

Tabel 11. Maximum displacement value and base reaction value

\begin{tabular}{|c|c|c|c|c|c|}
\hline \multirow[b]{2}{*}{ 望 } & \multirow{2}{*}{ 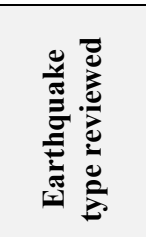 } & \multicolumn{2}{|c|}{$\begin{array}{l}\text { Displaceme } \\
\text { nt (m) }\end{array}$} & \multicolumn{2}{|c|}{ Base Shear (Kgf) } \\
\hline & & ^. & 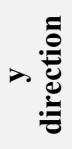 & × & $>\stackrel{\Xi}{\overparen{0}}$ \\
\hline \multirow{2}{*}{ 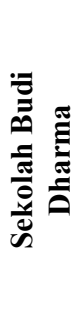 } & $\begin{array}{c}\text { USGS } \\
\text { Earthqua } \\
\text { ke Record }\end{array}$ & $\begin{array}{l}+ \\
0\end{array}$ & $\overrightarrow{\widetilde{o}}$ & 408276,62 & 339411,38 \\
\hline & $\begin{array}{c}\text { Estimated } \\
\text { Indonesia } \\
\text { Earthqua } \\
\text { ke Map } \\
2017\end{array}$ & $\overline{\tilde{\sigma}}$ & $\stackrel{0}{0}_{0}^{+}$ & 699841,47 & 349533,69 \\
\hline \multirow{2}{*}{ 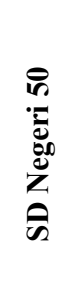 } & $\begin{array}{c}\text { USGS } \\
\text { Earthqua } \\
\text { ke Record }\end{array}$ & Oे & $\underbrace{0}_{0}$ & 502770,9 & 410214,3 \\
\hline & $\begin{array}{c}\text { Estimated } \\
\text { Indonesia } \\
\text { Earthqua } \\
\text { ke Map } \\
2017\end{array}$ & $\begin{array}{l}\hat{\vartheta} \\
\text { ठे } \\
0\end{array}$ & $\begin{array}{l}\tilde{O} \\
0 \\
0\end{array}$ & 259991,19 & 598606,47 \\
\hline
\end{tabular}

The table above shows that the Sekolah Budi Dharma building against the USGS earthquake recording is more flexible and prone to shifting in the y direction, on the contrary for the 2017 Indonesia earthquake map forecast it is more flexible and susceptible to shifting in the $\mathrm{x}$ direction. Meanwhile, the SD Negeri 50 building for the USGS earthquake record is more flexible and susceptible to shifts in the $\mathrm{x}$ direction, the estimated Indonesia earthquake map 2017 looks more flexible and vulnerable to shifts in the y direction. Based on the results of the largest value of the displacement monitor, it can be seen that the displacement in the Sekolah Budi Dharma building due to the burden of the USGS earthquake recording is smaller than the displacement due to the Puskim load, as well as the SD Negeri 50 building.

\subsubsection{The median value of spectral displacement graph point and damage the state's Sekolah Budi Dharma Banda Aceh}

The capacity spectrum curve is useful for getting the value of the median spectral acceleration parameter. This has been supported in the SAP2000 program. 
Furthermore, to form the seismic fragility curve of the building, it is necessary to determine the position of each damage state on the capacity spectrum curve. Determination of the position of each damage limit on the capacity spectrum curve based on research [6].

Based on Duan \& Pappin [6], the stages of identifying the capacity spectrum curve to obtain the median spectral displacement point value are as follows as shown in the graph below as well as determination of each damage state on the capacity spectrum curve is shown in the following figure.

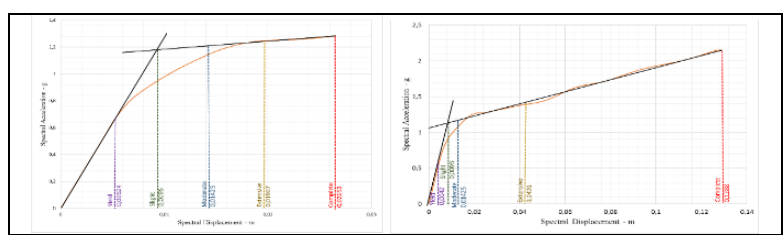

Fig. 12. Determination of damage state Capacity Spectral x-direction (USGS earthquake recording - Estimated 2017 earthquake map in Indonesia)

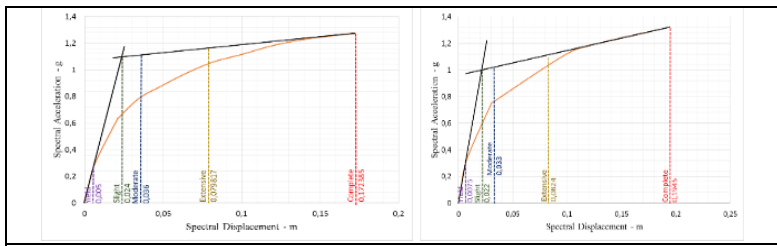

Fig. 13. Determination of damage state Capacity Spectral y-direction (USGS earthquake recording - Estimated map of Indonesia earthquake 2017)

The graph above was obtained from by the calculation of the ATC 40 Capacity Spectral curve, so we are able to determine the damage state curve for each building.

\subsubsection{Chart median spectral displacement point and damage state for SD Negeri 50}

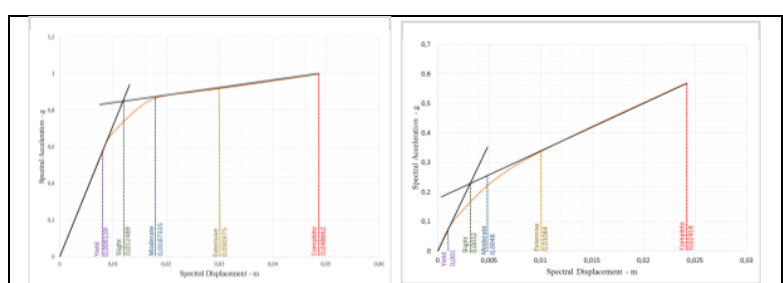

Fig. 14. Determination of damage state Capacity Spectral x-direction (USGS earthquake recording - Estimated 2017 earthquake map in Indonesia)

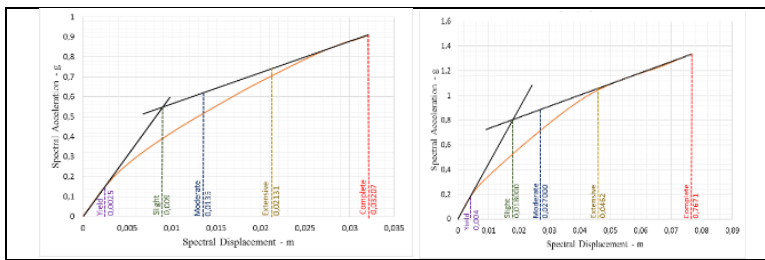

Fig. 15. Determination of damage state Capacity Spectral y-direction (USGS earthquake recording - Estimated map of Indonesia earthquake 2017)

As discussed above, the graph was obtained from the calculation of the ATC 40 Capacity Spectral curve, so that we can determine the damage state curve for each building.

\subsection{The results of the comparison analysis of the damage limit of the spectrum capacity curve}

The seismic capacity curve of the building is the relationship between the spectral acceleration as the horizontal axis and the probability of structural failure as the vertical axis. What is really needed in describing the fragility curve is the value of the acceleration spectra at each damage state. Based on the identification of the capacity spectrum curve in section 4.4 .3 and section 4.4.4, the spectral acceleration and spectral displacement points are generated for each structural failure condition as recapitulated in the table below.

1. The results of the spectral acceleration and spectral displacement points for the Sekolah Budi Dharma Banda Aceh

Tabel 12. $S_{d}$ and $S_{a}$ values for each type of structural damage to the Sekolah Budi Dharma Banda Aceh .

\begin{tabular}{|c|c|c|c|c|c|}
\hline \multirow{2}{*}{ 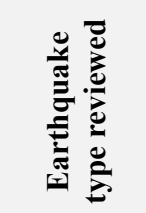 } & \multirow{2}{*}{ 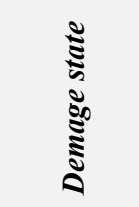 } & \multicolumn{2}{|c|}{$S_{d}, d s(m)$} & \multicolumn{2}{|c|}{ Sa,ds (g) } \\
\hline & & ^ঙ: & $>\stackrel{\Xi}{\stackrel{0}{0}}$ & $\rtimes \stackrel{\Xi}{\stackrel{0}{0}}$ & 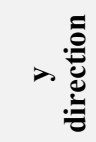 \\
\hline \multirow{4}{*}{ ص } & Slight & 0,0095 & 0,0240 & 0,9545 & 0,6664 \\
\hline & Moderate & 0,01425 & 0,0360 & 1,1435 & 0,7944 \\
\hline & Extensive & 0,0197 & 0,0798 & 1,2480 & 1,0496 \\
\hline & Complete & 0,0265 & 0,1724 & 1,2847 & 1,2730 \\
\hline \multirow{4}{*}{ 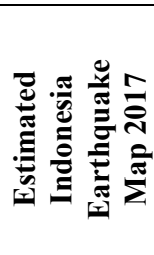 } & Slight & 0,0095 & 0,0220 & 0,9528 & 0,5960 \\
\hline & Moderate & 0,01425 & 0,0330 & 1,1125 & 0,7659 \\
\hline & Extensive & 0,0426 & 0,0824 & 1,3922 & 1,0315 \\
\hline & Complete & 0,1288 & 0,1945 & 2,1558 & 1,3212 \\
\hline
\end{tabular}

2. The results of the spectral acceleration and spectral displacement points for SD Negeri 50 Banda Aceh

Tabel 13. $S_{d}$ and $S_{a}$ values for each type of structural damage to the SD Negeri 50 Banda Aceh.

\begin{tabular}{|c|c|c|c|c|c|}
\hline \multirow{2}{*}{ 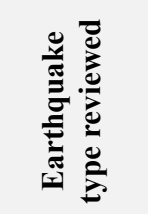 } & \multirow{2}{*}{$\begin{array}{l}0 \\
5 \\
5 \\
5 \\
5 \\
0 \\
5 \\
5\end{array}$} & \multicolumn{2}{|c|}{$S_{d}, d s(m)$} & \multicolumn{2}{|c|}{ Sa,ds (g) } \\
\hline & & メ & 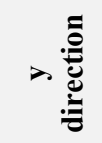 & 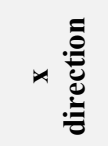 & 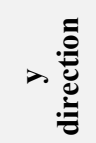 \\
\hline \multirow{4}{*}{ 总 } & Slight & 0,0125 & 0,0090 & 0,7519 & 0,3916 \\
\hline & Moderate & 0,01873 & 0,0135 & 0,8720 & 0,5910 \\
\hline & Extensive & 0,0304 & 0,0213 & 0,9201 & 0,7066 \\
\hline & Complete & 0,0487 & 0,0321 & 0,9953 & 0,9080 \\
\hline \multirow{3}{*}{ 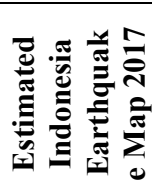 } & Slight & 0,0032 & 0,0180 & 0,1581 & 0,5060 \\
\hline & Moderate & 0,00480 & 0,0270 & 0,2048 & 0,6891 \\
\hline & Extensive & 0,0108 & 0,0462 & 0,3466 & 1,0278 \\
\hline
\end{tabular}




\begin{tabular}{|c|c|c|c|c|c|}
\hline \multirow{3}{*}{ 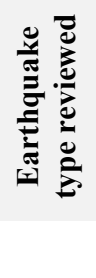 } & \multirow{2}{*}{\begin{tabular}{l}
8 \\
\multirow{3}{5}{} \\
5 \\
5 \\
3 \\
5 \\
5
\end{tabular}} & \multicolumn{2}{|c|}{$S_{d}, d s(m)$} & \multicolumn{2}{|c|}{ Sa,ds (g) } \\
\hline & & $\times \stackrel{\Xi}{\stackrel{0}{0}}$ & $>\stackrel{\Xi}{\stackrel{\Xi}{0}}$ & $\times \stackrel{\Xi}{\stackrel{\Xi}{0}}$ & $>\stackrel{\Xi}{\stackrel{0}{0}}$ \\
\hline & Complete & 0,0242 & 0,7671 & 0,5678 & 1,3376 \\
\hline
\end{tabular}

4.5.1 The result of the comparison of the percentage value of the probability value of the developed earthquake fragility curve

Based on subchapter 1, $\mathrm{S}_{\mathrm{a}}$ can be searched for each building, so it can be analyze the percentage of the probability of the developed curve. Data were obtained from the results of the Spectra response program on the Puskim portal.

1. Calculation of acceleration spectra for Sekolah Budi Dharma building

Where, $\mathrm{T}=0.518$ seconds

$\mathrm{T}_{0}=0.135799$ seconds

$\mathrm{T}_{\mathrm{S}}=0.678993$ seconds

$\mathrm{T}_{\mathrm{L}}=14,000000$ seconds

$\mathrm{S}_{\mathrm{D}}=1.001484 \mathrm{~g}$

Due to $\mathrm{T} \mathrm{T}_{0}$ or $\mathrm{T} T_{S}$, then the same as $\mathrm{S}_{\mathrm{DS}} S_{a}$ $S_{a}=1.001484 \mathrm{~g}$

Furthermore, to find out what percentage of the probability of a building experiencing damage limits is shown in the fragility curve below.
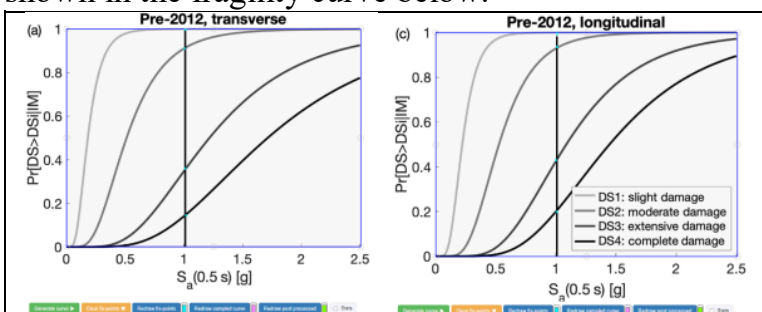

Fig. 16. Inserting an image with a value of $S_{a}$ and assigning a point to follow the graph in the $\mathrm{x}$-direction and $\mathrm{y}$-direction

2. Calculation of acceleration spectra for SD Negeri 50 . buildings

$$
\text { Where, } \quad \begin{aligned}
\mathrm{T} & =0.611 \text { second } \\
\mathrm{T}_{0} & =0.135816 \text { seconds } \\
\mathrm{Ts} & =0.679080 \text { seconds } \\
\mathrm{T}_{\mathrm{L}} & =12000000 \text { seconds } \\
\mathrm{SD} & =1.001354 \mathrm{~g}
\end{aligned}
$$

Due to T T0 or T $\leq T S$, then the same as SDS. $S_{a}$ $S_{a}=1.001354 \mathrm{~g}$

From the calculation above, it can be seen the percentage probability of the developed curve. The curve taken by the study on the fragility curve from the journal Natural Hazards and Earth System Sciences by Gentile, et al (2019).

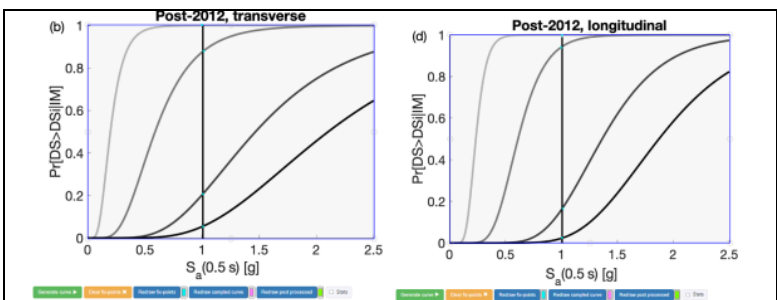

\begin{tabular}{|c|c|c|c|c|}
\hline \multirow{2}{*}{$\begin{array}{l}\text { Building } \\
\text { reviewed }\end{array}$} & \multirow{2}{*}{$\begin{array}{c}\text { Demage } \\
\text { state }\end{array}$} & \multirow{2}{*}{$\underset{\text { மூ }}{20}$} & \multicolumn{2}{|c|}{ Probabilitas (\%) } \\
\hline & & & $\begin{array}{c}\mathbf{x} \\
\text { direction } \\
\end{array}$ & $\begin{array}{c}\mathbf{y} \\
\text { direction }\end{array}$ \\
\hline \multirow{4}{*}{$\begin{array}{l}\text { Sekolah } \\
\text { Budi } \\
\text { Dharma }\end{array}$} & Slight & \multirow{4}{*}{ 离 } & 99.7 & 99.5 \\
\hline & Moderate & & 91 & 93.6 \\
\hline & Extensive & & 35.9 & 43.1 \\
\hline & Complete & & 14.4 & 20.1 \\
\hline \multirow{4}{*}{$\begin{array}{c}\text { SD Negeri } \\
\mathbf{5 0}\end{array}$} & Slight & \multirow{4}{*}{ 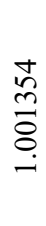 } & 100 & 99.8 \\
\hline & Moderate & & 87.8 & 94 \\
\hline & Extensive & & 20.9 & 16.6 \\
\hline & Complete & & 5.7 & 2.4 \\
\hline
\end{tabular}

Fig. 17. Inserting an image with a value of $S_{a}$ and assigning a point to follow the graph in the $\mathrm{x}$-direction and y-direction

Tabel 14. Percentage probability for each type of structural damage to the building under review.

Comparison of the value of $\mathrm{S}_{\mathrm{a}}$ and the probability of the building as shown in Table 14, it can be concluded that the greater the value of $S_{a}$ of the building (Sekolah Budi Dharma), the greater the percentage of the probability of moderate, severe and total damage. This is also influenced by the Sekolah Budi Dharma building which was established before the earthquake and tsunami on December 26, 2004. Meanwhile, SD Negeri 50 has a small value of $\mathrm{S}_{\mathrm{a}}$, so that the probability of total damage is getting smaller.

\subsection{Tsunami load calculation results}

\subsubsection{The results of the analysis of the inter-story drift the tsunami load floors}

\begin{tabular}{|c|c|c|c|c|c|}
\hline $\begin{array}{c}\text { School } \\
\text { building }\end{array}$ & $\frac{\dot{0}}{\dot{0}}$ & 馬 & $\begin{array}{l}\text { Displace } \\
\text { ment } \mathrm{x}\end{array}$ & $\begin{array}{l}\text { The drift } \\
\text { between } \\
\text { floors }\end{array}$ & $\begin{array}{c}\text { Deviation } \\
\text { between } \\
\text { floors } \\
\text { permits } \\
\end{array}$ \\
\hline & & (m) & (m) & (m) & (m) \\
\hline \multirow{3}{*}{ 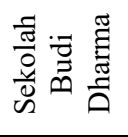 } & 3 & 3,5 & 0,000087 & $-0,000067$ & 0.035 \\
\hline & 2 & 3,5 & 0,000154 & 0,000081 & 0.035 \\
\hline & 1 & 3,5 & 0,000073 & 0,000073 & 0.035 \\
\hline \multirow{3}{*}{ 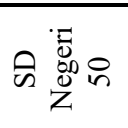 } & 3 & 4 & 0,000078 & 0,000050 & 0,08 \\
\hline & 2 & 4 & 0,000028 & 0,000022 & 0,08 \\
\hline & 1 & 4 & 0,000006 & 0,000006 & 0,08 \\
\hline
\end{tabular}

The results of the deviation between floors to the combination of tsunami loads which were occur in each school is shown in Table 15 and Table 16.

Tabel 15. Deviation between floors due to tsunami direction 
Tabel 16. Deviation between floors due to tsunami direction

\begin{tabular}{|c|c|c|c|c|c|}
\hline $\begin{array}{l}\text { School } \\
\text { building }\end{array}$ & $\frac{\grave{0}}{\grave{0}}$ & $\overline{\bar{\pi}}$ & $\begin{array}{l}\text { Displacem } \\
\text { ent } \mathrm{x}\end{array}$ & $\begin{array}{c}\text { The drift } \\
\text { between } \\
\text { floors }\end{array}$ & $\begin{array}{c}\text { Deviatio } \\
\mathrm{n} \\
\text { between } \\
\text { floors } \\
\text { permits }\end{array}$ \\
\hline & & (m) & (m) & (m) & (m) \\
\hline \multirow{3}{*}{$\begin{array}{l}\text { Sekolah } \\
\text { Budi } \\
\text { Dharma }\end{array}$} & 3 & 3,5 & 0,002143 & 0,000105 & 0.035 \\
\hline & 2 & 3,5 & 0,002038 & 0,000615 & 0.035 \\
\hline & 1 & 3,5 & 0,001423 & 0,001423 & 0.035 \\
\hline \multirow{3}{*}{$\begin{array}{c}\text { SD Negeri } \\
50\end{array}$} & 3 & 4 & 0,001222 & 0,000077 & 0,08 \\
\hline & 2 & 4 & 0,001145 & 0,000145 & 0,08 \\
\hline & 1 & 4 & 0,001 & 0,001000 & 0,08 \\
\hline
\end{tabular}

Based on the table above, it can be seen that the deviation between floors in the $\mathrm{x}$ and $\mathrm{y}$ directions based on SNI 1726: 2019 [3] has met the criteria because the deviation between floors does not exceed the allowed deviation between floors.

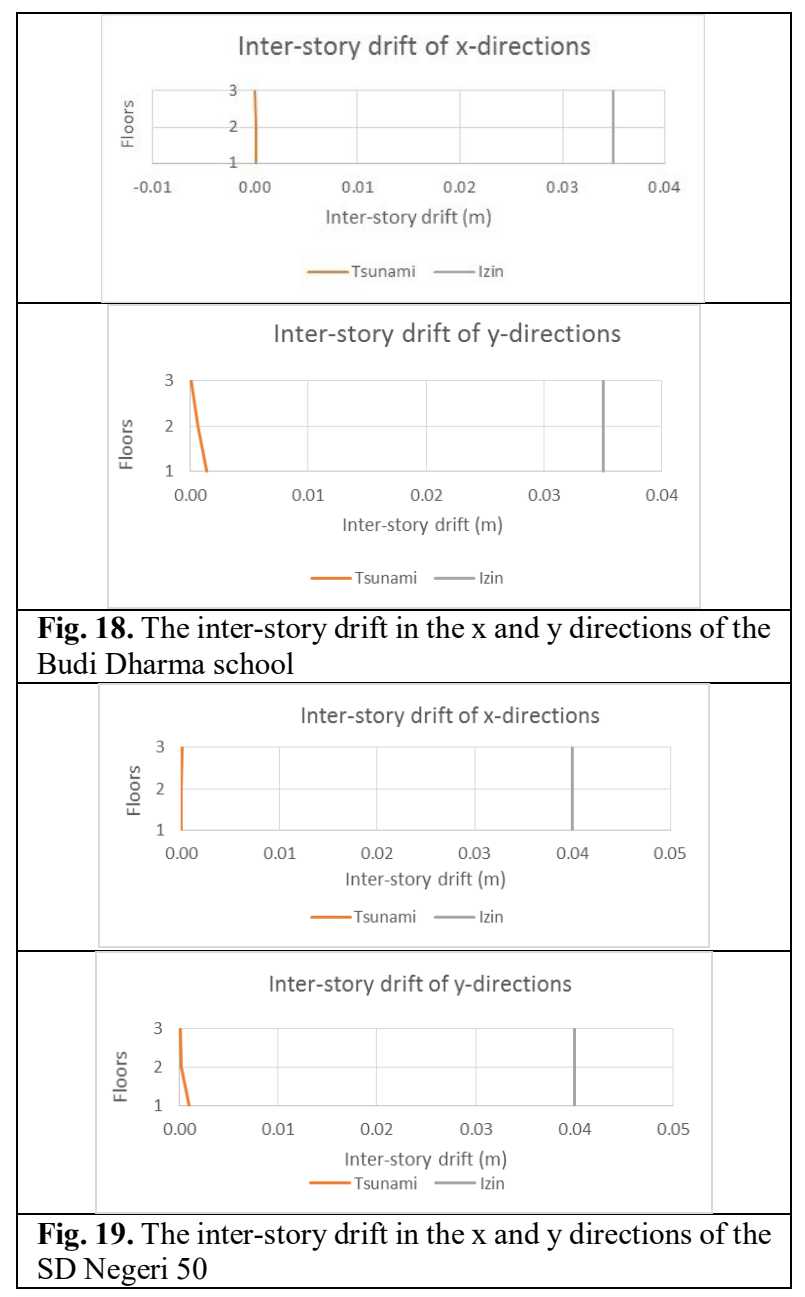

In Figures 18-19 it suggested that the deviation between floors due to earthquake loads has exceeded the permit limit based on SNI 1726:2019 [3] so that the treatment of buildings due to earthquake loads must be strengthened so that the building can withstand tsunami loads.
4.6.2 The results of the comparison of the percentage probability values of the developed tsunami fragility curve

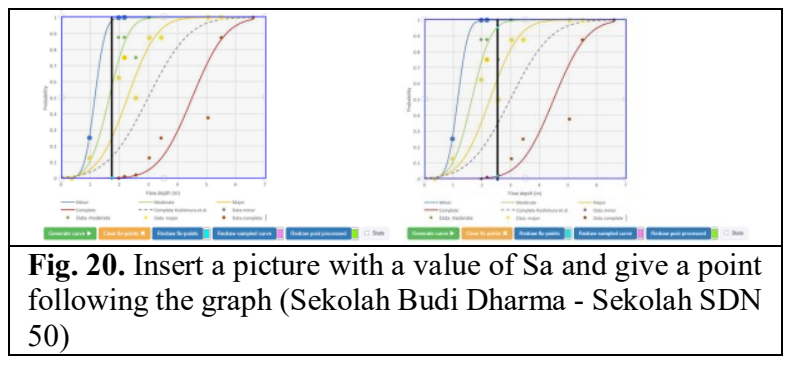

Tabel 17. Comparison of damage state results to probability

\begin{tabular}{|c|c|c|c|}
\hline $\begin{array}{l}\text { Building } \\
\text { reviewed }\end{array}$ & $\begin{array}{c}\text { Demage } \\
\text { state }\end{array}$ & $\begin{array}{c}\text { Flow } \\
\operatorname{depth}(\mathrm{m})\end{array}$ & Probabilitas (\%) \\
\hline \multirow{4}{*}{$\begin{array}{c}\text { Sekolah } \\
\text { Budi } \\
\text { Dharma }\end{array}$} & Minor & \multirow{4}{*}{1,8} & 97 \\
\hline & Moderate & & 57 \\
\hline & Major & & 25 \\
\hline & Complete & & 0.5 \\
\hline \multirow{4}{*}{ SDN 50} & Minor & \multirow{4}{*}{2,6} & 100 \\
\hline & Moderate & & 94 \\
\hline & Major & & 62 \\
\hline & Complete & & 1,4 \\
\hline
\end{tabular}

Based on the results of the graphs and tables above, it can be drawn a comparison of the two school buildings if the greater the value of the tsunami inundation height on the SD Negeri 50 building, the greater the level of light, medium, heavy and total damage when given a tsunami load. At the Sekolah Budi Dharma, because it has a smaller height than SD Negeri 50, it produces a smaller percentage probability value for the level of damage.

\section{Conclusions and recommendation}

\subsection{Conclusion}

1. Based on nonlinear statistical analysis the $\mathrm{x}$ direction shows the maximum displacement value of the two buildings was $0.21 \mathrm{~m}$ and the base shear value was $699841.47 \mathrm{Kgf}$, while in the y direction the maximum displacement value of the two buildings was $0.21 \mathrm{~m}$ and the base shear value was 339411,38 kgf.

2. The spectral acceleration $\left(\mathrm{S}_{\mathrm{a}}\right)$ value of the capacity spectrum of Sekolah Budi Dharma was $1.001484 \mathrm{~g}$ and SD Negeri 50 was $1.001354 \mathrm{~g}$.

3. The results of the comparison of the value of $S_{a}$ and the probability of the two buildings when viewed against the earthquake is obtained if the value of $S_{a}$ is large, the greater the percentage of the probability of moderate, severe and total damage is also influenced by the building being reviewed before the earthquake and tsunami on 26 December 2004 (Sekolah Budi Dharma ). 
4. The results of the comparison of the two school buildings, if the greater the value of the tsunami inundation height on the SD Negeri 50 building, the greater the level of light, medium, heavy and total damage when viewed from the tsunami hazard. At the Sekolah Budi Dharma, because it has a smaller height than SD Negeri 50, it produces a smaller percentage probability value for the level of damage.

\subsection{Recommendation}

1. Further research is expected to be able to make variations of earthquake modeling based on other earthquake sources in order to get different spectral response values.

2. In this study, what is analyzed is the existing building with structural data through thorough research results, it is hoped that further research will use building structural data such as draft drawings, concrete compressive strength test results, and steel tensile test results applied to which buildings will be used. make seismic fragility curves and tsunami fragility curves more accurate.

\section{References}

1. Bayong, T. HK. (2006). Ilmu Kebumian dan Antariksa, PT Remaja Rosdakarya, Bandung.

2. Badan Standarisasi Nasional. 2020. Standar Nasional Indonesia 1727-2020: Beban Desain Minimum dan Kriteria Terkait untuk Perancangan Bangunan Gedung dan Struktur Lain, Badan Standarisasi Nasional: Jakarta.

3. Badan Standarisasi Nasional. 2019. Standar Nasional Indonesia 1726-2019: Tata Cara Perencanaan Ketahanan Gempa untuk Struktur Bangunan Gedung dan Non Gedung. Badan Standarisasi Nasional: Jakarta.

4. Federal Emergency Management Agency. (2019). Guidelines for Design of Structures for Vertical Evacuation from Tsunami Second Edition. Department of Homeland Security FEMA Mitigation Division: Washington D.C.

5. Dewobroto, W. (2005). Evaluasi Kinerja Struktur Baja Tahan Gempa dengan Analisis Pushover, Prosiding Civil Engineering National Conference: Sustainability Construction \& Structural Engineering Based on Professionalism, 27 hal, Universitas Katolik Soegijapranata, Semarang.

6. Duan, X., dan Pappin, JW. (2008). A Procedure for Establishing Fragility Functions for Seismic Loss Estimate of Existing Buildings Based on Nonliner Pushover Analysis, dipresentasikan pada The 14th World Conference on Earthquake Engineering, Beijing, 12-17 Oktober.

7. HAZUS (Hazard US), (1999): Earthquake Loss Estimation, National Institute of Building Sciences. NIBS: Washington D.C.

8. Badan Standarisasi Nasional. 2013. Standar Nasional Indonesia 2847 :2013: Persyaratan Beton
Struktural untuk Bangunan Gedung. Badan Standarisasi Nasional: Jakarta.

9. Gentile, R., Galasso, C., Idris, Y., Rusydy, I., dan Meilianda, E. (2019). From Rapid Visual Survey to Multi-Hazard Risk Prioritisation and Numerical Fragility of School Buildings, Nat. Hazards Earth Syst. Sci., 19, 1365-1386.

10. Iemura, H., Pradono, M. H., Sugimoto, M., Takahashi, Y., dan Husen, A. (2012). Tsunami Height Memorial Poles In Banda Aceh And Recommendations For Disaster Prevention, Proceedings of the International Symposium on Engineering Lessons Learned from the 2011 Great East Japan Earthquake, Tokyo, Japan, March 1-4.

11. Syamsidik, Benazir, Lutfi, M., Suppasri, A., dan Comfort, L. K. (2020). The 22 December 2018 Mount Anak Krakatau volcanogenic tsunami on Sunda Strait coasts, Indonesia: tsunami and damage characteristics, NHESS, 20(2), 549-565.

12. Kostov, M. (2000). Seismic Fragility Analysis, dipresentasikan pada Regional Workshop on External Events PSA, Sofia, Bulgaria, 6-10 November. 